\title{
Cocoa Cortex Ashes as Fluxing Additive for Vitrified Ceramic Making from Alluvial Clay
}

\author{
E. J. A. Ndzana1, D. Njoya ${ }^{1 *}$, A. Elimbi', G. V. Ranaivoarivo², G. Lecomte-Nana ${ }^{3}$, A. N. Nzeukou4, \\ D. Njopwouo ${ }^{1}$
}

\author{
${ }^{1}$ Department of Inorganic Chemistry, Faculty of Science, University of Yaoundé 1, Yaoundé, Cameroon \\ ${ }^{2}$ Laboratoire de Chimie Minérale de l'Ecole Supérieure Polytechnique, Équipe de Recherche Géosciences, Matériaux Minéraux, \\ Organique et Gemmes, Université d'Antananarivo, Antananarivo, Madagascar \\ ${ }^{3}$ Laboratoire SPCTS, Centre Européen de la Céramique, Université de Limoges, Limoges Cedex, France \\ ${ }^{4}$ Local Material Promotion Authority, Yaoundé, Cameroon \\ Email: ^dayirou2000@yahoo.fr, *dnjoya@uy1.uninet.cm
}

How to cite this paper: Ndzana, E.J.A., Njoya, D., Elimbi, A., Ranaivoarivo, G.V., Lecomte-Nana, G., Nzeukou, A.N. and Njopwouo, D. (2019) Cocoa Cortex Ashes as Fluxing Additive for Vitrified Ceramic Making from Alluvial Clay. Journal of Materials Science and Chemical Engineering, 7, 24-39.

https://doi.org/10.4236/msce.2019.710003

Received: August 27, 2019

Accepted: October 19, 2019

Published: October 22, 2019

Copyright (C) 2019 by author(s) and Scientific Research Publishing Inc. This work is licensed under the Creative Commons Attribution International License (CC BY 4.0).

http://creativecommons.org/licenses/by/4.0/

\begin{abstract}
The aim of this study is to use Cocoa Cortex Ash (CCA) as alternative fluxing agent to manufacture vitrified ceramics at low temperatures from alluvial clay. Specimens of mixtures including clay and CCA (0\%, 10\%, 20\% and 30\% by mass) were used and fired respectively at $1050^{\circ} \mathrm{C}$ and $1100^{\circ} \mathrm{C}$. X-ray diffraction and scanning electron microscopy were carried out. $\gamma$-alumine, mullite, akermanite, anorthite and grossular are new crystalline phases formed. Also, technological properties were determined on fired specimens as a function of CCA mass percentage. The results showed that firing shrinkage increased up to $8.5 \%$ for specimens with $10 \%$ by mass of CCA, then lessened up to $2 \%$ for specimens with $30 \%$ by mass of CCA. When fired at $1100^{\circ} \mathrm{C}$, the specimens that initially contained $10 \%$ by mass of CCA allowed the formation of compact bodies with water absorption of $2 \%$ and flexural strength of $32 \mathrm{MPa}$. Hence, mixed at low percentage with poorly fluxing kaolinite clay, CCA can be used successfully as flux for the production of vitrified ceramics such as stoneware at low temperatures. The mixture of CCA with kaolinitic clay also promotes the formation of mullite and anorthite at low temperature.
\end{abstract}

\section{Keywords}

Poorly Fluxing Clay, Cocoa Cortex Ash, Flux, Stoneware

\section{Introduction}

Vitrified ceramics are known for their quasi impermeability, their durability, their excellent mechanical performance and their resistance to corrosion and 
chemical agents. They can be designated by porcelain or stoneware, depending on the purity of the raw material. They are used for domestic purposes as sanitary bodies, in construction as wall and floor tiles, and even in the environmental protection as sanitation pipes [1]. Vitrified ceramics are manufactured either from a clay alone containing enough amounts of fluxing oxides or from a mixture of poorly fluxing clay and additive fluxes. The firing temperature is usually between $1120^{\circ} \mathrm{C}$ and $1300^{\circ} \mathrm{C}$ [2] [3] [4]. Low sintering temperatures lead to insufficient maturation and less compact products with important amount of pores. Also, very high temperature leads to deformation of specimens as a result of the formation of great quantity of viscous phase due to the flux content [2] [3] [4] [5]. Feldspars are fluxes generally used for manufacturing vitrified ceramics because of their high content in alkali oxides such as $\mathrm{K}_{2} \mathrm{O}$ and $\mathrm{Na}_{2} \mathrm{O}$ which are responsible of the vitrification process. The formation of vitreous phase is favorable to improve densification of the products, mechanical properties and decrease of the water absorption because of few amounts of pores [6] [7]. Fluxes also influence the new minerals phase formation and the microstructure of the firing products during sintering. However, difficult access to pure feldspars and sometimes their high melting point due to the presence of other phases such as quartz [8] led some authors to experiment with other sources of flux: Ergul et al. [7] have studied the physical properties of a batch of specimens composed of $50 \%$ by mass of basaltic tuffs and $50 \%$ by mass of industrial clay at $1150^{\circ} \mathrm{C}$. Elsewhere, for the manufacture of wall tiles, Das et al. [9] used kaolinitic clay with other raw materials including fly ash, wollastonite and dolomite and obtained products whose flexural strength reached $30 \mathrm{MPa}$ at $1150^{\circ} \mathrm{C}$. For the preparation of glass-ceramic, $\mathrm{Vu}$ et al. [10] formulated a mixture composed of bottom ash ( $80 \%$ by mass) and fly ash (20\% by mass) to get specimens which were fired at $950^{\circ} \mathrm{C}$. Kamseu et al. [11] used pegmatite and nepheline syenite to experiment at $1175^{\circ} \mathrm{C}$ low process of porcelainzed stoneware and to evaluate pore size distribution. Recently, Njindam et al. [12] used glass powder with clay mixture to manufacture porcelain stoneware wall and floor tiles at $1150^{\circ} \mathrm{C}$. The production of cocoa is well developed in most tropical regions around the world, and such exploitation leads to a significant volume of cocoa cortex waste. Cultivation of Cocoa is very large in the world-wide. Cameroon is the world's fifth large producer of Cocoa, and it is closely concerned with the valorization of such waste [13]. The cocoa cortex which represents $68 \mathrm{wt} \%$ of the whole fruit, carries a toadstool responsible for brown rot on cocoa plants. The valorization of this waste is effective in sectors such as agriculture and livestock [14]. When cocoa cortex is calcined at $1000^{\circ} \mathrm{C}$, the obtained ashes contains high amount of potassium oxide, which make this waste a potential flux source for the manufacturing of vitrified ceramics. Regarding the existing literature, the effect of cocoa cortex ashes (CCA) on the mechanism of novel phases formation and the microstructure of clay based vitrified ceramics has not yet experimented. The present works is focusing on the elaboration of vitrified ceramic at low temperature using cocoa cortex ashes as alternative fluxing agent for improve vitrification of ceramic 
made from a poorly fluxing clay. The raw materials and the fired one were submitted to X-ray diffraction, electronic microscope and physico-mechanical testing for the evaluation of the phase conversion from raw to fired product and performances of the fired products.

\section{Materials and Experimental Techniques}

Analluvial clay (EB) collected from the locality of Ebebda, (Center Region of Cameroon) according to the following geological coordinates: $04^{\circ} 23^{\prime} 30^{\prime \prime} \mathrm{N}$ and $11^{\circ} 15^{\prime} 21^{\prime \prime} \mathrm{W}$ ) is used. This clay is grey with random appearance of red and brown spots, compact and very plastic. According to Munsel Code [15], its dried powder color code is 5YR6/4 (brown). Crude cocoa cortex was collected in a cocoa farm also located at Ebebda. The collected cortex, was washed with distilled water, oven dried at $105^{\circ} \mathrm{C}$, ground and sieved over a100 $\mu \mathrm{m}$ mesh. The cocoa cortex ash (CCA), was obtained afterfiring the raw cocoa cortex powder at $1000^{\circ} \mathrm{C}$ in a programmable electrical furnace (Nabertherm, model $\mathrm{LH}$ 60/14) at a heating rate of $5^{\circ} \mathrm{C} / \mathrm{min}$ and soaking time of two hours. The ashes was furnace cooled to room temperature, and sieved over a $100 \mu \mathrm{m}$ mesh and store in polyethylene bags prior to their use. Powdered raw materials were subject to chemical analysis and X-ray diffraction analysis. The chemical composition of the raw materials (alluvial clay and cocoa cortex ash) was obtained using a XRF PANalytical Zetium Spectrometer. The XRD pattern was registered using a Bruker Advanced D8 diffractometer device, with $\mathrm{Cu} \mathrm{K} \alpha=1.5418 \AA$ and the JCPDF files were used for mineralogical identification. For the ceramic bodies, mixtures of raw materials (alluvial kaolinite clay and cocoa cortex ash) were made by varying the content of CCA from $0 \%$ to $30 \%$ by mass to get specimens denoted as C0, C10, C20 and C30 respectively (Table 1). Each mixture was moistened with distilled water ( $5 \%$ by mass) and the obtained paste was molded and pressed using anuniaxial hydraulic press (SPECAC Model). Test samples forms and dimensions were the following: parallelepiped $(2 \mathrm{~cm} \times 2 \mathrm{~cm} \times 6 \mathrm{~cm})$ for determination of flexural strength and firing shrinkage; cylindrical (height $6 \mathrm{~mm}$; diameter 12 $\mathrm{mm}$ ) to determine bulk density, apparent porosity and microstructure. The resulted specimens were dried at ambient temperature of laboratory for 48 hours and then oven dried at $105^{\circ} \mathrm{C}$ till constant mass. Before being fired at $1050^{\circ} \mathrm{C}$ and $1100^{\circ} \mathrm{C}$ in a programmable electric furnace (Nabertherm, Model LH 60/14), the thermal behavior of the alluvial kaolinite clay and the experimented mixtures were obtained through differential scanning calorimetry (DSC), thermogravimetric

Table 1. Composition of the mixtures expressed as percentage by mass.

\begin{tabular}{ccc}
\hline specimens & EB & CCA \\
\hline C0 & 100 & 0 \\
C10 & 90 & 10 \\
C20 & 80 & 20 \\
C30 & 70 & 30
\end{tabular}


(TG) and dilatometric analyses. Dilatometric analysis was done using a Setaram TMA Setsys Evo device at $5^{\circ} \mathrm{C} / \mathrm{min}$ under air, while the DSC and TG analyses were obtained by using coupled DSC/TGA NETZSCH STA 429 (CD) equipment under air at $10^{\circ} \mathrm{C} / \mathrm{min}$. For DSC/TG experiments, a Pt crucible was used for both sample and reference powders, the reference material used consisted of alumina powder previously heated at $1600^{\circ} \mathrm{C}$. Firing shrinkage was determined according to ASTM C326-03 [16], water absorption, bulk density were determined according to the normNF EN ISO 10545-3 [17], and Flexural strength was measured in accordance with the normNF EN ISO 10545-4 [18], using an electro hydraulic press ( $M \& O$, model). Scanning Electron Microscopy (SEM) was achieved using a QUANTA 450 FEG microscope equipped with LINK -OXFORD XLII EDAX system.

\section{Results and Discussion}

\subsection{Raw Materials Characterization}

\subsubsection{Chemical Composition and Mineralogy}

Chemical compositions of alluvial clay (EB), CCA and the experimented mixtures $(\mathrm{C} 0, \mathrm{C} 10, \mathrm{C} 20$ and $\mathrm{C} 30)$ are given in Table 2. Also, Figure 1 gives the EDS spectrum of powder of cocoa cortex ash (CCA).

EB is mainly composed of $\mathrm{SiO}_{2}$ (53.05\% by mass), $\mathrm{Al}_{2} \mathrm{O}_{3}(22.12 \%$ by mass) and $\mathrm{Fe}_{2} \mathrm{O}_{3}\left(7.87 \%\right.$ by mass). So, the silica $\left(\mathrm{SiO}_{2}\right)$ and alumina $\left(\mathrm{Al}_{2} \mathrm{O}_{3}\right)$ contents are corresponding to kaolinite content in the sample, along with the presence of hematite as impurity. The color of the clay (brown, 5YR6/4) according to Munsel Code is probably related to the presence of both $\mathrm{Fe}_{2} \mathrm{O}_{3}$ and $\mathrm{TiO}_{2}(2.5 \%$ by mass). The value of the loss on ignition in $\mathrm{EB}$ ( $12.5 \%$ by mass) is close to that

Table 2. Chemical compositions of EB and CCA, and the mixtures (C10 and C20 and C30).

\begin{tabular}{cccccc}
\hline OXIDES & EB (\% by mas) & CCA (\%) & C10 (\%) & C20 (\%) & C30 (\%) \\
\hline $\mathrm{SiO}_{2}$ & 53.05 & 3.73 & 48.13 & 43.19 & 38.25 \\
$\mathrm{Al}_{2} \mathrm{O}_{3}$ & 22.12 & 1.05 & 20.01 & 17.90 & 15.80 \\
$\mathrm{~K}_{2} \mathrm{O}$ & 1.17 & 45.83 & 5.63 & 10.10 & 14.57 \\
$\mathrm{Na}_{2} \mathrm{O}$ & 0.12 & 0.21 & 0.13 & 0.14 & 0.14 \\
$\mathrm{Fe}_{2} \mathrm{O}_{3}$ & 7.87 & 0.42 & 7.17 & 6.38 & 5.64 \\
$\mathrm{TiO}_{2}$ & 2.50 & 0.14 & 2.26 & 2.03 & 1.79 \\
$\mathrm{MgO}$ & 0.37 & 7.71 & 1.05 & 1.73 & 2.41 \\
$\mathrm{CaO}$ & 0.05 & 10.23 & 1.07 & 2.09 & 3.11 \\
$\mathrm{P}_{2} \mathrm{O}_{5}$ & 0.11 & 6.29 & 0.73 & 1.35 & 1.95 \\
$\mathrm{MnO}^{\mathrm{NrO}}$ & $/$ & 0.13 & 0.013 & 0.026 & 0.039 \\
$\mathrm{SrO}_{\mathrm{SO}}$ & $/$ & 0.13 & 0.013 & 0.026 & 0.039 \\
$\mathrm{LOI}$ at $1050^{\circ} \mathrm{C}$ & 12.46 & 22.12 & 0.249 & 0.498 & 0.747 \\
\hline
\end{tabular}




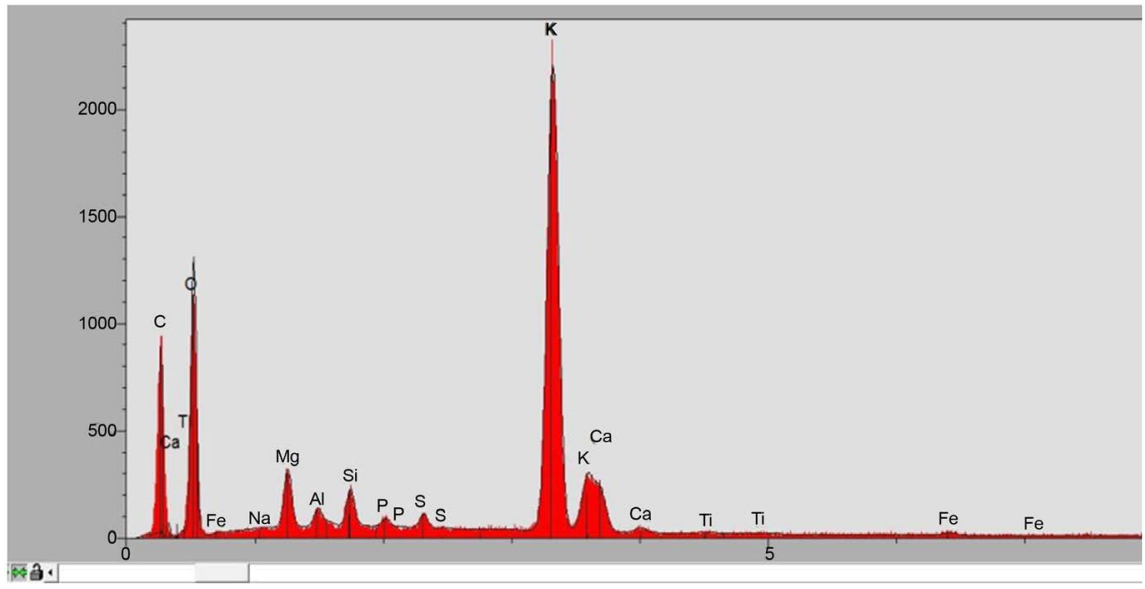

Figure 1. EDS analysis of CCA.

observed by Pialy et al. and Nkoumbou et al. [19] [20] within kaolinitic clays. Cocoa cortex ash exhibits high content of $\mathrm{K}_{2} \mathrm{O}$ (45.83\% by mass) (Table 2 and Figure 1), which is of interest for the use of CCA as a flux source. Also, $\mathrm{Al}_{2} \mathrm{O}_{3}$ ( $1.05 \%$ by mass), $\mathrm{SO}_{3}$ (2.49\% by mass), $\mathrm{SiO}_{2}$ (3.17\% by mass), $\mathrm{P}_{2} \mathrm{O}_{5}(6.28 \%$ by mass), $\mathrm{MgO}$ ( $7.17 \%$ by mass) and $\mathrm{CaO}(10.23 \%$ by mass $)$ are present in CCA and could indicate the presence of various compounds. Other oxides as $\mathrm{Fe}_{2} \mathrm{O}_{3}$, $\mathrm{Na}_{2} \mathrm{O}, \mathrm{TiO}_{2}, \mathrm{MnO}, \mathrm{SrO}$ are also present in CCA at very low content. X-ray diffraction pattern of EB shows that kaolinite (JCPDF 01-0527) is the main mineral phase. It is associated to hematite (JCPDF 03-0812), rutile (JCPDF 77-0443) and quartz (JCPDF 89-8937) (Figure 2(a)). X-ray pattern of CCA (Figure 2(b)) shows the presence of arcanite (JCPDF 24-0703), potassium phosphate oxide (JCPDF 08-0225), potassium oxide (JCPDF 77-2176) and Merwinite (JCPDF 02-0949) as crystalline phases.

SEM observation of EB shows pseudo hexagonal platelets of kaolinite with irregular shape (Figure 3) which indicates that the latter mineral is not well crystallized [21]. SEM observation of CCA shows white flocculated clusters of variable forms with black stains that can be assigned to carbon resulted by combustion of organic matter.

\subsubsection{Thermal Behavior of Alluvial Clay and Experimented Mixtures} The thermal analyses curves (DSC and TG) of EB and of the mixtures C10 and C30 are shown in Figure 4. The three DSC curves exhibit an endothermic peak with the maximum between $95^{\circ} \mathrm{C}$ and $116^{\circ} \mathrm{C}$ which corresponds to elimination of hygroscopic water. For the specimens $\mathrm{C} 10$ and $\mathrm{C} 30$, the latter peak increased with increasing amount of CCA and it was accompanied by a significant weight loss. Indeed, according to our observation, when the powder of CCA was in contact with ambient air of laboratory, it became more and more moisten, which explains its increase content of hygroscopic water. The weak exothermic peak observed in EB at $290^{\circ} \mathrm{C}$ is assigned to decomposition of organic matter [19] [21]. The second endothermic peak with maximum located between $490^{\circ} \mathrm{C}$ and $516^{\circ} \mathrm{C}$ corresponds to the dehydroxylation of kaolinite, which is transformed 


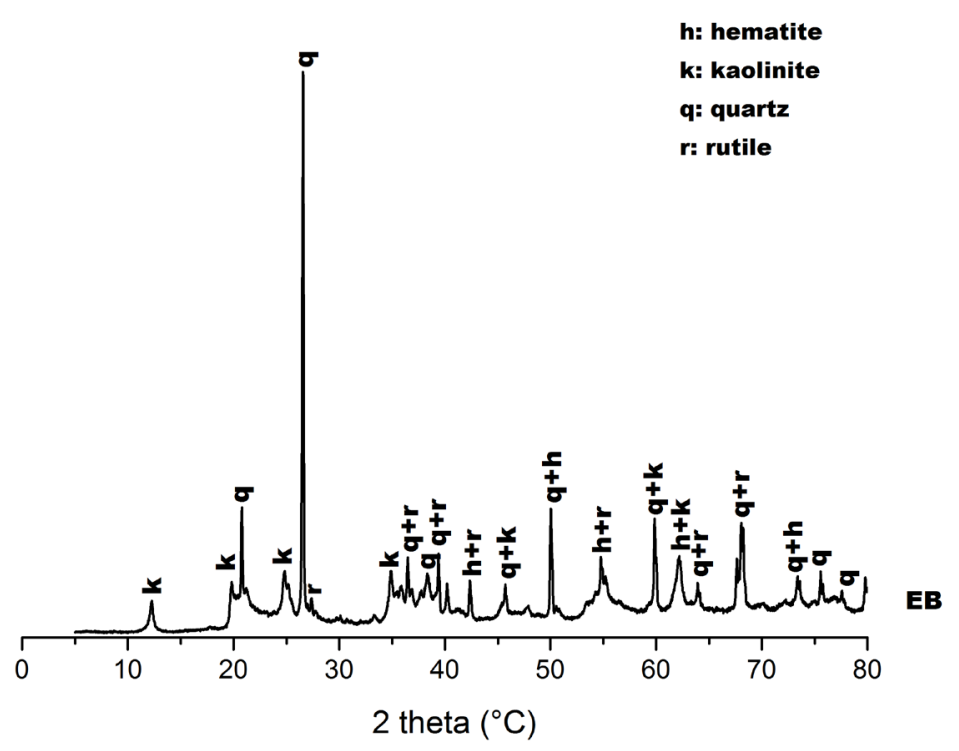

(a)

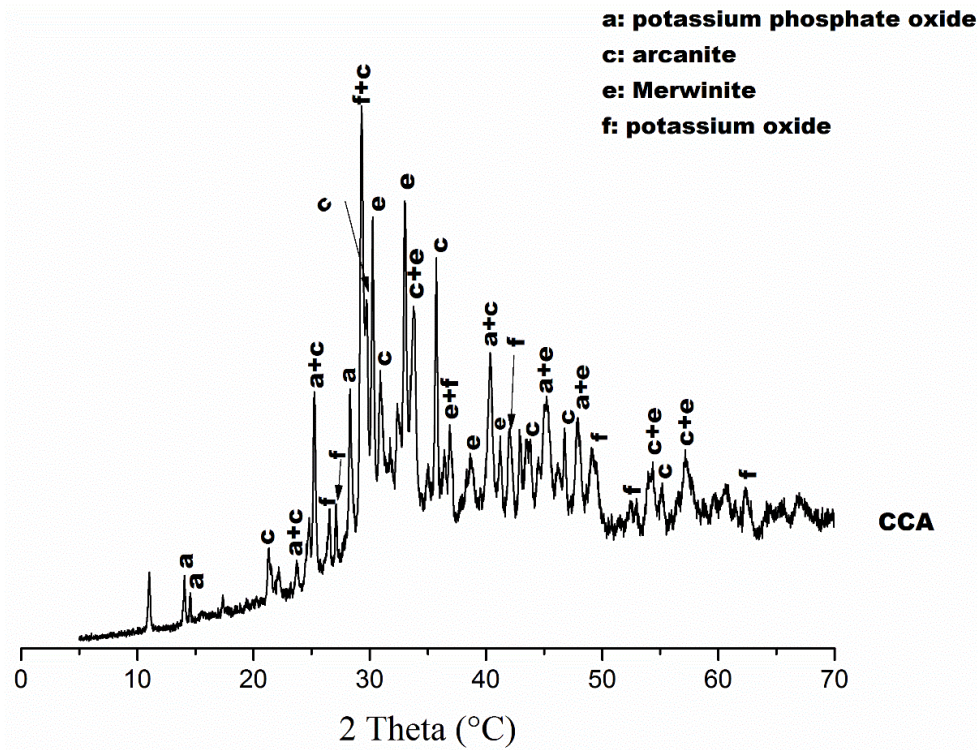

(b)

Figure 2. XRD patterns of EB and CCA.
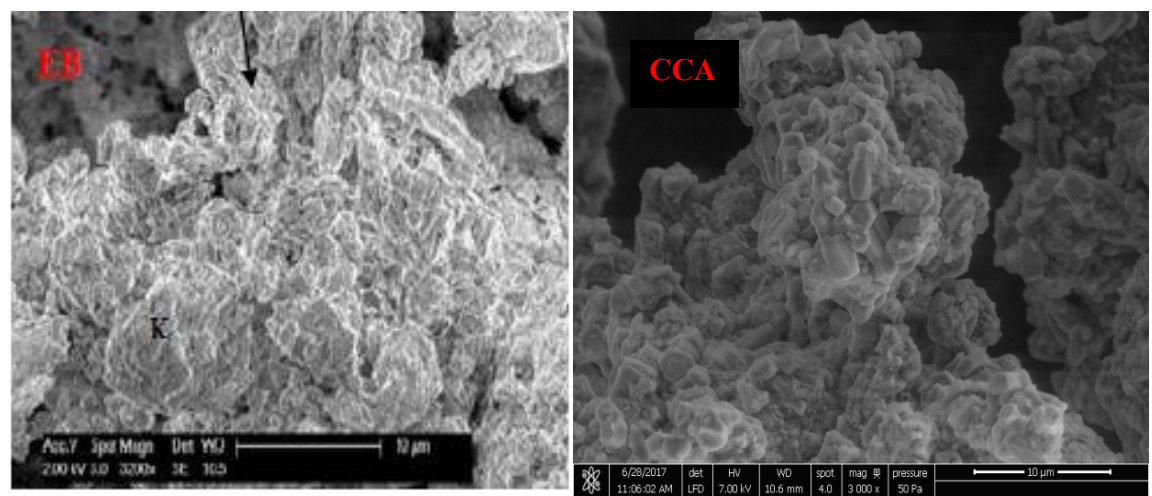

Figure 3. SEM micrographs of EB and CCA. 


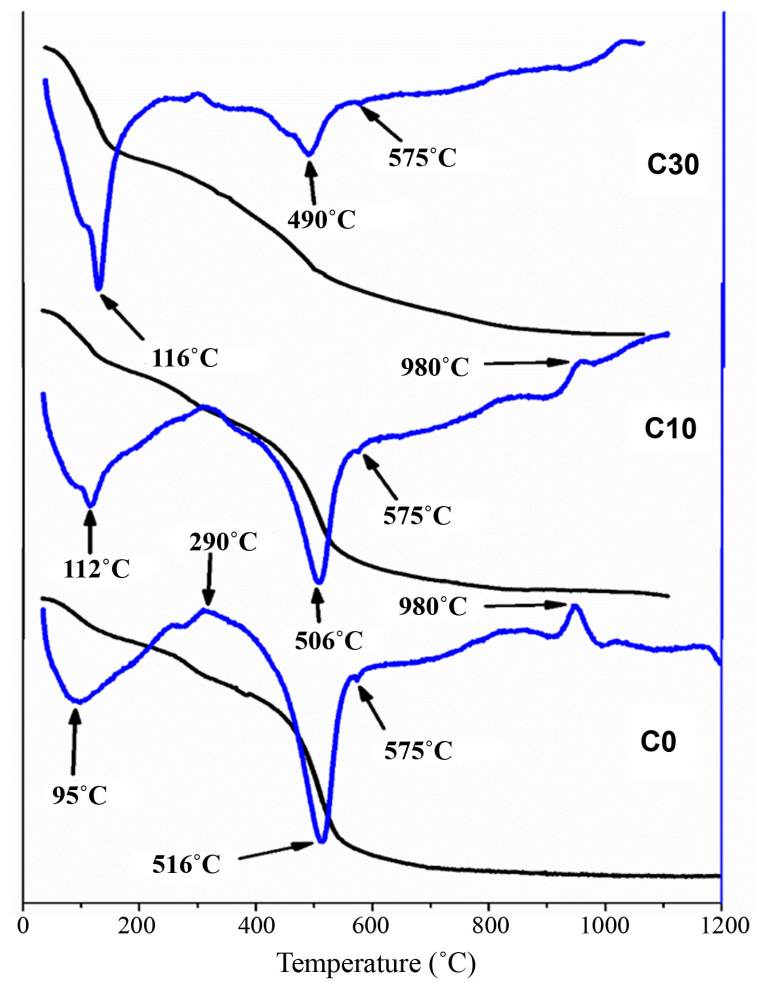

Figure 4. TGA and DSC curves of specimens C0 and C10 and C30.

into metakaolinite. With the increase of CCA amount (Table 1), the latter peak shifted to low temperatures. The weak endothermic peak at $575^{\circ} \mathrm{C}$ corresponds to the polymorphic transformation of quartz $\alpha$ to quartz- $\beta$ [22] [23]. The exothermic peak related to the rearrangement of metakaolinite network around $980^{\circ} \mathrm{C}$ decreased with CCA increasing and it became hardly observable in the mixture C30 probably due to the interaction between metakaolinite and the secondary phase or to the diffusion of potassium contained in CCA [24] [25] [26] [27]. Figure 5 shows the dilatometric behavior of $\mathrm{C} 0$ (EB) and C10. In each, or the other curve the first shrinkage between $575^{\circ} \mathrm{C}$ and $700^{\circ} \mathrm{C}$ corresponds to the dehydroxylation of kaolinite (Figure 4). This shrinkage appears earlier in C10 than $\mathrm{C} 0$ probably due to the $\mathrm{K}_{2} \mathrm{O}$ content in CCA. The second shrinkage around $900^{\circ} \mathrm{C}-975^{\circ} \mathrm{C}$ could correspond to the transformation of metakaolinite into either a spinel phase or mullite [28] [29]. At temperatures greater than $975^{\circ} \mathrm{C}$, there is a great shrinkage which is the result of sintering that includes solid state diffusion and viscous flow mechanisms. It is likely that the consolidation of CCA containing sample is enhanced, and begins at a lower temperature in comparison to EB sample behavior.

\subsection{Fired Products Characterization}

\subsubsection{Mineral Transformation and Micro Morphological Changes}

Figure 6 \& Figure 7 show the X-ray patterns of samples fired at $1050^{\circ} \mathrm{C}$ and $1100^{\circ} \mathrm{C}$ respectively. Quartz, hematite, rutile and $\gamma$-alumine occurred in all fired samples. Mullite appeared from $\mathrm{C} 10$ to $\mathrm{C} 30$ at $1050^{\circ} \mathrm{C}$ and from $\mathrm{C} 0$ at $1100^{\circ} \mathrm{C}$. 


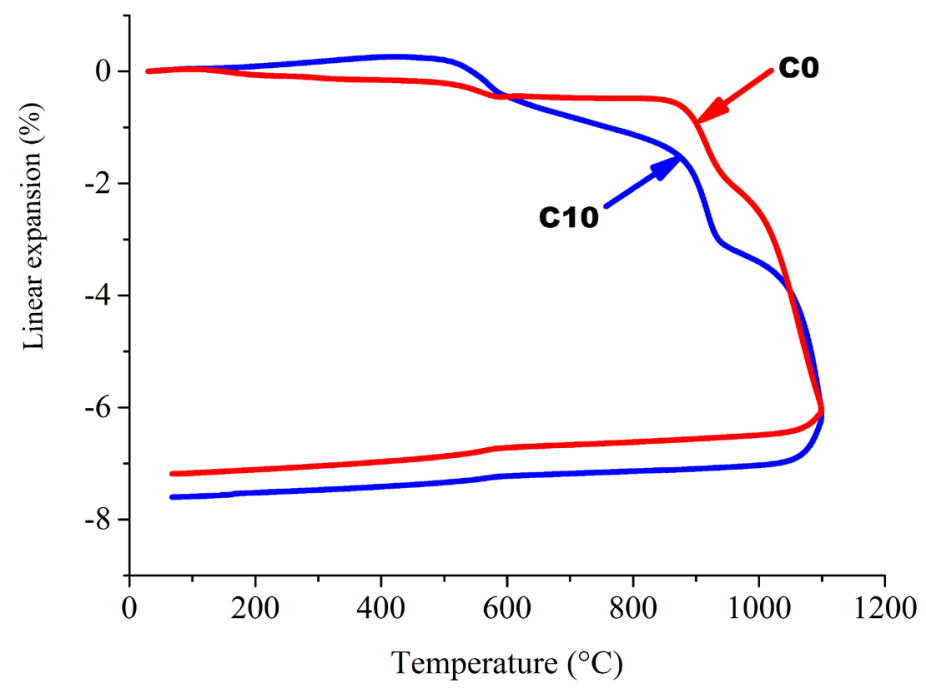

Figure 5. Dilatometric curves of specimens C0 and C10.

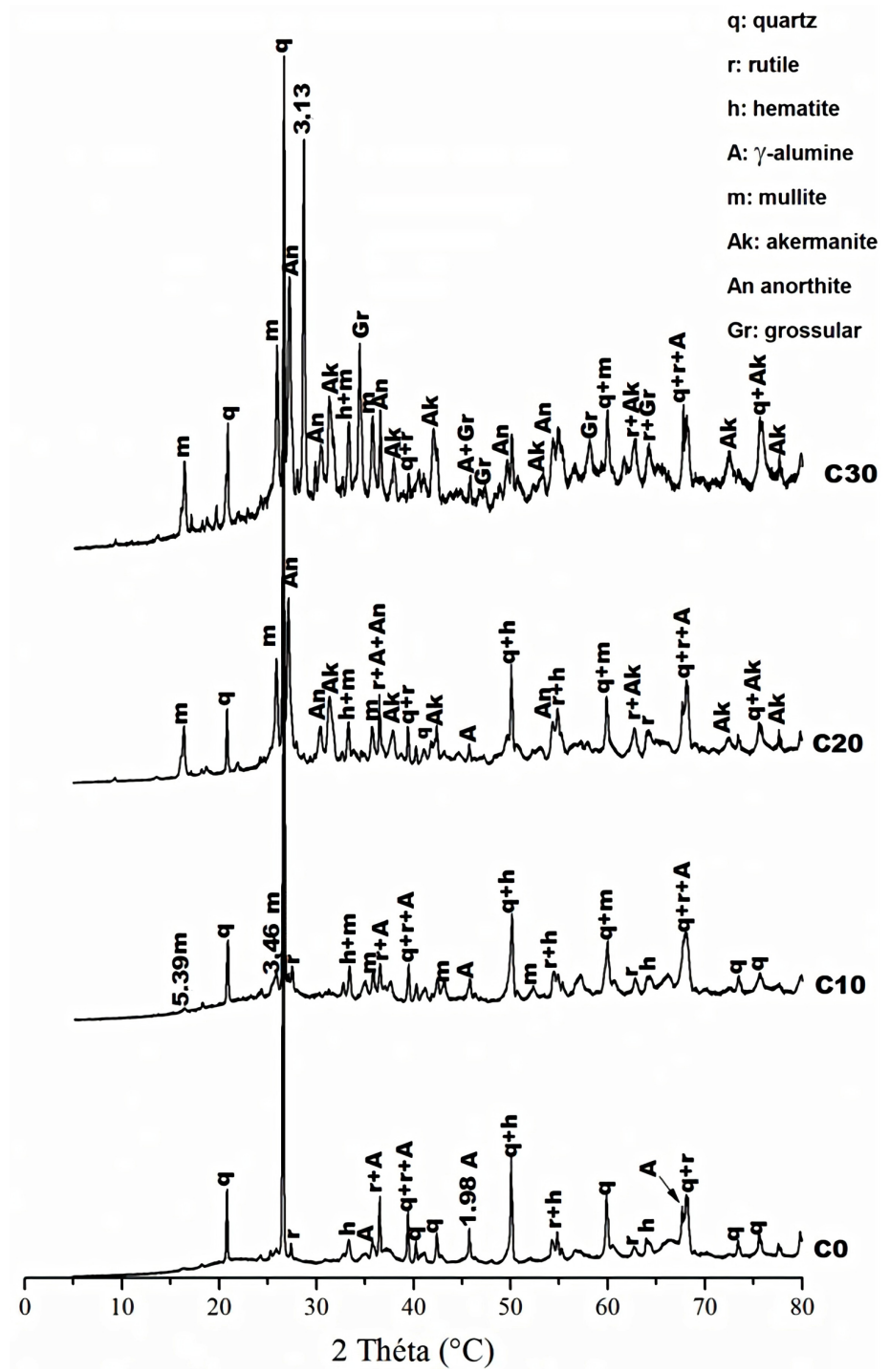

Figure 6. XRD patterns of specimens fired at $1050^{\circ} \mathrm{C}$. 


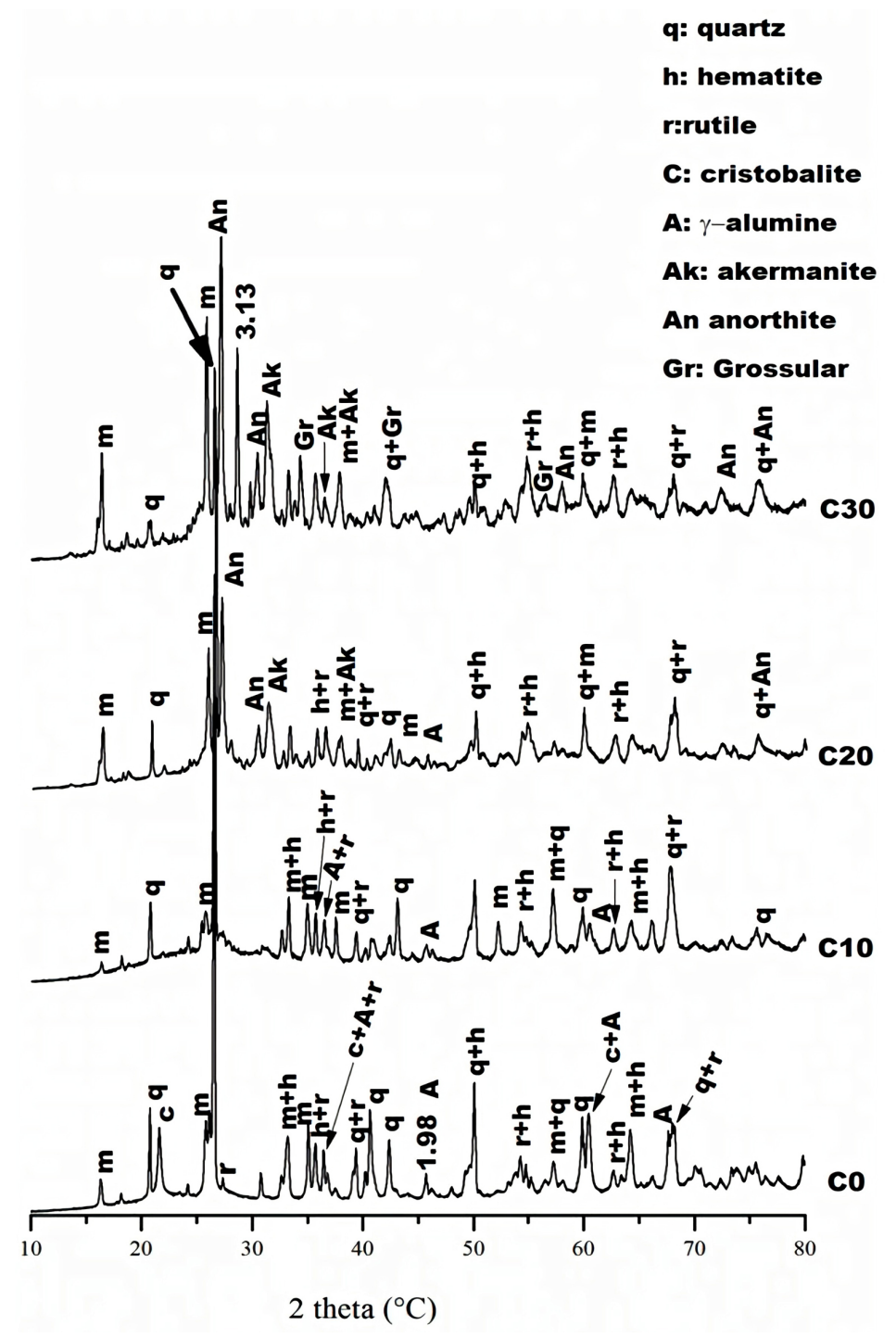

Figure 7. XRD patterns of specimens fired at $1100^{\circ} \mathrm{C}$.

Cristoblite is observed only at $1100^{\circ} \mathrm{C}$ on $\mathrm{C} 0$ sample. The latter crystalline phase is absent in specimens $\mathrm{C} 10$ - C30 probably as a result of its dissolution in the increase glassy phase formed [30] [31]. Anorthite and akermanite are found in C20 and C30 fired mixtures. The $\gamma$-alumine phase observed results from the discharge of Al from clay minerals [32] [33]. Its main peak intensity (1.98 $⿱$ ) diminishes with increasing amount of CCA in both temperatures, due to the decrease amount of clay minerals or its involvement to new minerals formation. The presence of CCA in the samples leads to the formation of mullite at lower temperature (Figure 6). Mullite main peaks intensities (5.39 $\AA$ and $3.46 \AA$ ) increase with increasing CCA content and temperature. The diffusion of potassium contained in CCA modifies structural reorganization process of metakaolinite. The exothermic peak around $980^{\circ} \mathrm{C}$ is strongly diminished (Figure 4) and leads to the mullite crystallization at lower temperatures [24]. Reaction of merwinite, quartz and sometimes aluminum silicates (clay minerals) give way to the forma- 
tion of calcium and magnesium metastable phases, as grossular $\left(\mathrm{Ca}_{3} \mathrm{Al}_{2} \mathrm{Si}_{3} \mathrm{O}_{12}\right)$ and akermanite $\left(\mathrm{Ca}_{2} \mathrm{MgSi}_{2} \mathrm{O}_{7}\right)$. Main peaks intensities of quartz (4.26 $\AA 3.34 \AA$ ), $\gamma$-alumine $(1.98 \AA)$, grossular $(2.62 \AA)$ lessen when temperature and CCA increase respectively from $1050^{\circ} \mathrm{C}$ to $1100^{\circ} \mathrm{C}$ and from $20 \%$ to $30 \%$ by mass, while anorthite main peaks intensities ( $3.25 \AA, 2.92 \AA$ ) increase. The formation of the latter mineral can be presented according to the following reaction:

$$
\begin{gathered}
\mathrm{Ca}_{3} \mathrm{Al}_{2} \mathrm{Si}_{3} \mathrm{O}_{12} \text { (grossular) }+3 \mathrm{SiO}_{2} \text { (quartz) + } \\
2 \mathrm{Al}_{2} \mathrm{O}_{3} \text { (alumine) } \rightarrow 3 \mathrm{CaAl}_{2} \mathrm{Si}_{2} \mathrm{O}_{8} \text { (anorthite) }
\end{gathered}
$$

SEM images and EDS spectra of the specimens C0, C10, C20 and C30 fired at $1100^{\circ} \mathrm{C}$ are given in Figure 8. All the micrographs show compact specimens except the one free from CCA (Figure 8(a)) which exhibits large pores as a result of absence of vitreous phase. The specimen $\mathrm{C} 10$ is more compact and denser than the specimens C20 and C30. Also, the glassy phase is well spread in C10
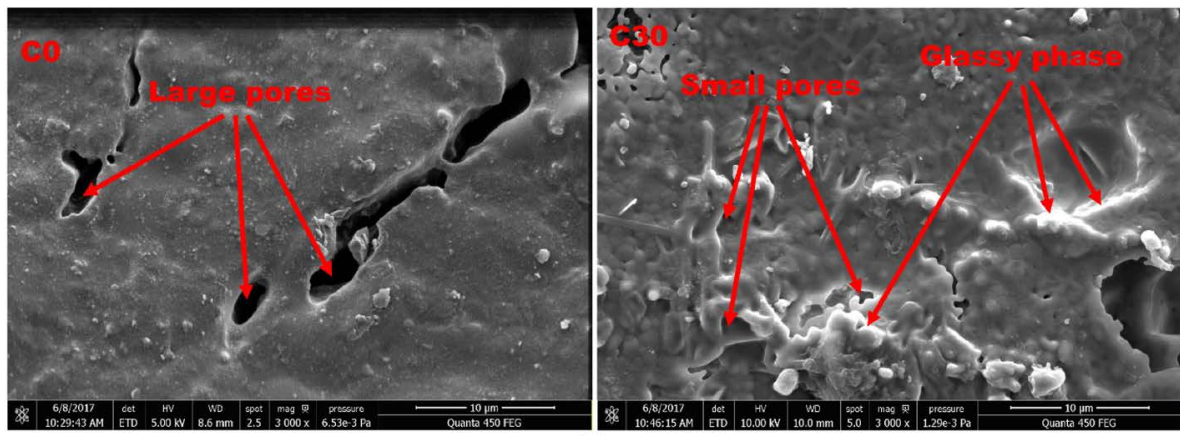

(a)

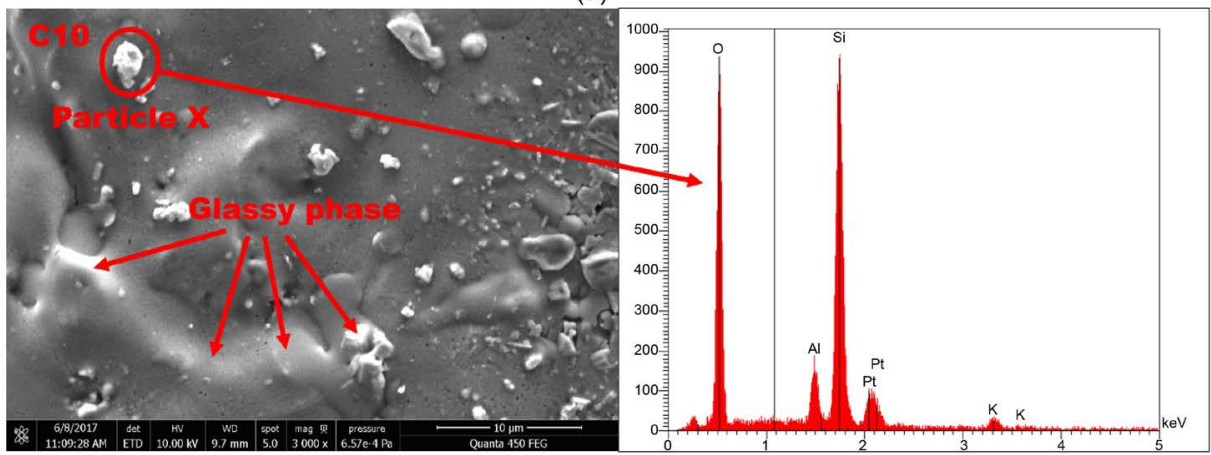

(b)
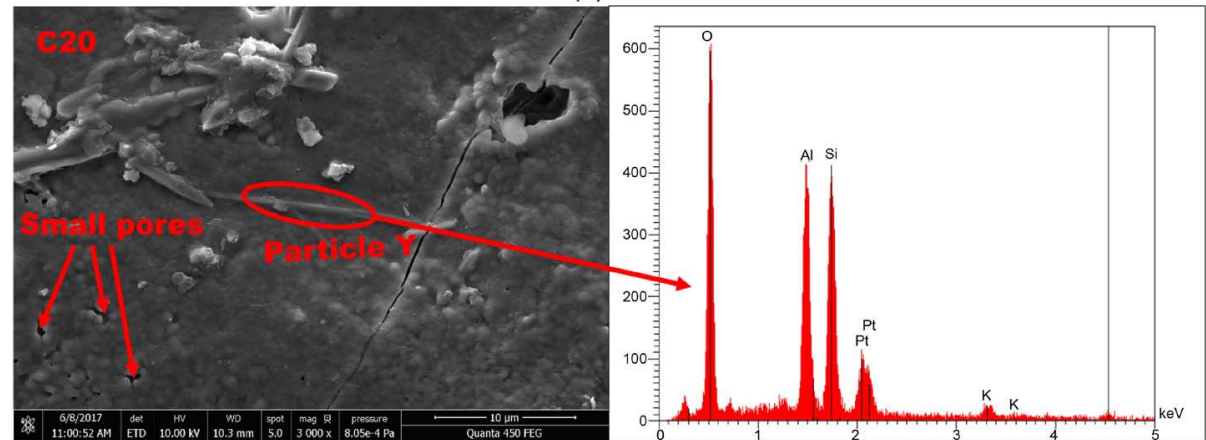

(c)

Figure 8. SEM micrographs and EDS spectra of specimens sintered at $1100^{\circ} \mathrm{C}((\mathrm{a})=\mathrm{C} 0$; $(\mathrm{b})=$ $\mathrm{C} 10 ;(\mathrm{c})=\mathrm{C} 20 ;(\mathrm{d})=\mathrm{C} 30)$. 
than in $\mathrm{C} 20$ and C30, the latter specimens exhibiting pores, due probably to the organic origin of ash and/or emission of gas from thermal decomposition of arcanite (Figure 2(b)). Indeed, Vassileva et al. [34] showed that from $1100^{\circ} \mathrm{C}$, there is a thermal decomposition of arcanite according to the reaction:

$$
\mathrm{K}_{2} \mathrm{SO}_{4} \text { (arcanite) } \rightarrow \mathrm{K}_{2} \mathrm{O} \text { (potassium oxide) }+\mathrm{SO}_{3} \text { (gas) }
$$

From EDS spectra, the main chemical elements observed in the "particle $\mathrm{x}$ " are silicon and oxygen (specimen C10) while in the "particle y" (specimens C20) there are aluminum, silicon and oxygen. The latter observations are in accordance with that of XRD (Figure 6 and Figure 7) that showed in a major extent, the presence of quartz in C10 while both quartz and mullite are observed in C20 and C30. Also, the presence of the latter crystalline phase is highlighted by the presence of needles [35] in Figure 8(c).

\subsubsection{Physical and Mechanical Properties}

The densification behavior of the fired bodies was evaluated via physical (firing shrinkage, apparent porosity and bulk density) and mechanical properties (flexural strength) as a function of CCA amount in specimens fired respectively at $1050^{\circ} \mathrm{C}$ and $1100^{\circ} \mathrm{C}$. Firing shrinkage and bulk density firstly increased respectively till $8.5 \%$ and $2.41 \mathrm{~g} / \mathrm{cm}^{3}$ for specimen with $10 \%$ mass of CCA, thereafter they lessen for specimens C20 and C30 (Figure 9(a) \& Figure 9(b)). This drop results from the formation of increasing amount of anorthite. Indeed the sintered bodies' volume increase with anorthite formation [36] [37]. Also, specimens with $10 \%$ by mass of CCA (C10) leads to the decrease of water absorption (WA) up to $5 \%$ and $2 \%$ respectively at $1050^{\circ} \mathrm{C}$ and $1100^{\circ} \mathrm{C}$. Conversely, WA increases for specimens with $20 \%$ or $30 \%$ by mass of CCA (Figure $9(\mathrm{c})$ ). The decrease of WA in fired products is due to the sintering phenomenon. This sintering is favored by the formation of a glassy phase due to the fluxes from CCA. As far as, increasing amount of CCA, leads to the formation of abundant glassy phase in the fired products. However, the glassy phase is concomitantly accompanied by pores released from emission of gas $\left(\mathrm{SO}_{3}\right)$ induced by the thermal transformation of arcanite $\left(\mathrm{K}_{2} \mathrm{SO}_{4}\right)$ which generates pores. Hence, fired specimens C20 and C30 contain both abundant glassy phase along with pores (Figure 8) which lead to concomitant increase of WA and decrease of bulk density (BD). The formation of anorthite (Figure 6 \& Figure 7) which increases the fired body's volume can also explained the decrease of BD for specimen C20 and C30 (Figure $9(\mathrm{~b}))$. For one to another firing temperature $\left(1050^{\circ} \mathrm{C}\right.$ or $\left.1100^{\circ} \mathrm{C}\right)$, there is increase of flexural strength for specimens $\mathrm{C} 0$. This is in accordance with Figure 6 and Figure 7 which show the formation of mullite only for the specimens fired at $1100^{\circ} \mathrm{C}$. As for the fired specimens $\mathrm{C} 10-\mathrm{C} 30$, there is an increase of flexural strength $(\sigma)$ up to $32 \mathrm{MPa}$ (Figure $9(\mathrm{~d})$ ) by addition of $10 \%$ by mass of CCA followed by a drop for specimens with great amount of additive. At $1100^{\circ} \mathrm{C}$, Cocoa cortex ash (up to $10 \%$ by mass) lead to vitrified ceramics with better technological properties compare to other flux agents. For example, Elimbi et al. [38] used syenite and nepheline syenite as fluxing agent with kaolinitic 


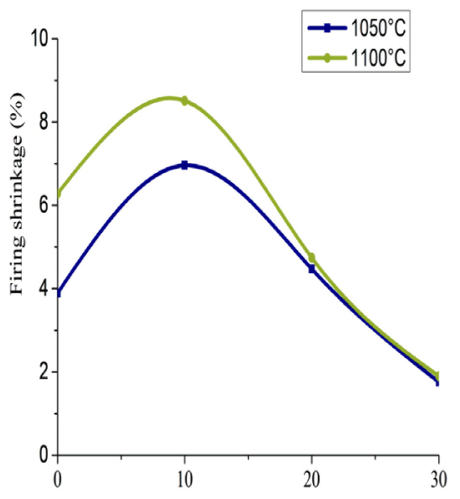

(a)

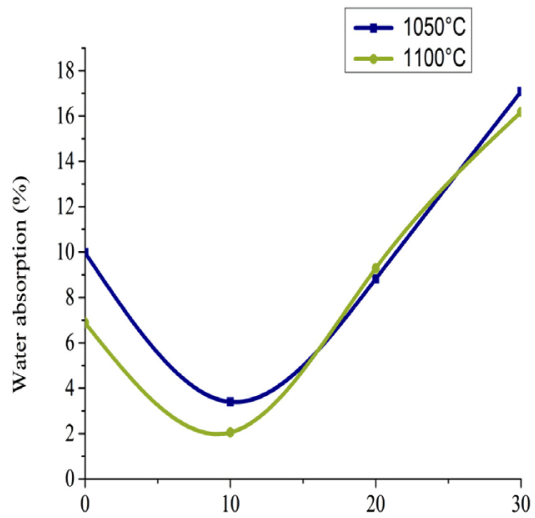

(c)

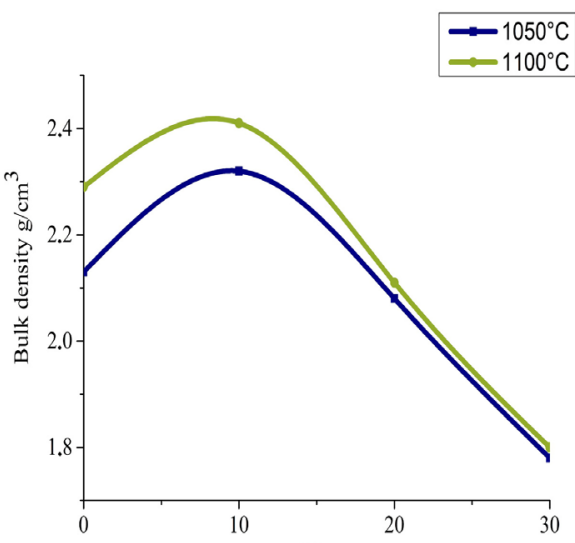

(b)

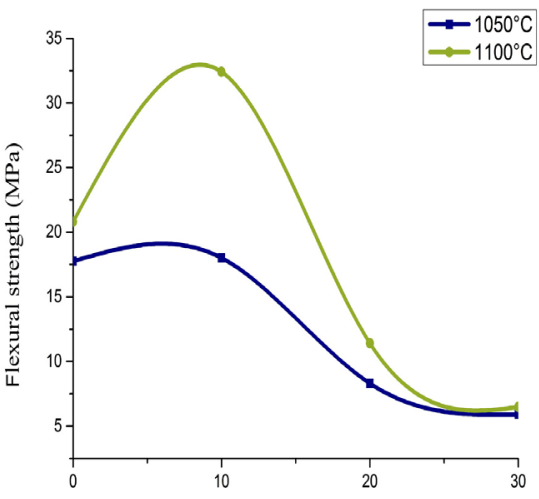

(d)

Figure 9. Physical and mechanical characteristics of fired bodies as a function of CCA mass percentage ((a) firing shrinkage; (b) bulk density; (c) water absorption; (d) flexural strength).

clay to manufacture vitrified ceramics. With the syenite and nepheline syenite content varied from $10 \%$ to $25 \%$ by mass and fired at $1100^{\circ} \mathrm{C}$, flexural strength of the obtained products is less than $15 \mathrm{MPa}$; in the same way, Njindam et al. [12] with addition of $10 \%$ by mass of glass powder in kaolinitic clay, obtained specimens with a flexural strength of $12 \mathrm{MPa}$ and $20 \mathrm{MPa}$ respectively at $1100^{\circ} \mathrm{C}$ and $1200^{\circ} \mathrm{C}$. In the micrograph of specimen $\mathrm{C} 10$, the product is compact contrarily to specimens $\mathrm{C} 20$ and C30 whose micrographs show pores (Figure 8). Hence, when fired at $1100^{\circ} \mathrm{C}$, specimens with $10 \%$ by mass of CCA led to products that correspond to vitrified ceramics such as stoneware, according to the norm ISO 13006 [39].

\section{Conclusion}

The objective of this work was to manufacture vitrified ceramics using Cocoa Cortex Ash (CCA), as fluxes source, and a poor fluxes containing alluvial clay. The effect of cocoa cortex ash was investigated on mineralogy, microstructure as well as on technological properties of fired products obtained from its mixtures with the alluvial clay. Crystalline phases initially present in CCA disappeared in the fired bodies, due to their involvement in the vitrification and/or in the new 
mineralization process. New crystalline phases formed are mullite, anorthite and grossular. $\gamma$-alumine phase was also formed due to release of $\mathrm{Al}$ from clay minerals. At $1100^{\circ} \mathrm{C}$, the specimens that was initially free from CCA contained cristobalite as a neo-formed crystalline phase but the latter was absent in the specimens which initially contained the additive, probably as a result of its dissolution in a vitreous phase. All the specimens fired at $1100^{\circ} \mathrm{C}$ were compact but the one which was free from CCA exhibited large pores. When fired, the specimens that initially contained $10 \%$ by mass of CCA were more compact and exhibited low water absorption $(2 \%)$, high density $\left(2.41 \mathrm{~g} / \mathrm{cm}^{3}\right)$ and flexural strength $(\sigma)$ of 32 MPa. Conversely, when fired, specimens that initially contained $20 \%$ or $30 \%$ by mass of CCA showed both abundant glassy phases along with pores which led to the increase of water absorption and decrease of both bulk density and flexural strength. The present research work pointed out that cocoa cortex ashes are effective source of fluxes for vitrified dense ceramics, such as stoneware, at dosage $\leq 10 \%$ and at lowered temperature of $1100^{\circ} \mathrm{C}$.

\section{Acknowledgements}

The authors are grateful to the Partenariat interuniversitaire entre P AFRique et POcéan Indien pour le Développement (PAFROID); Programme de mobilité universitaire intra-ACP; lot Afrique pour une action No. 2013-4644/001-001 avec la référence: 38421-EM-1-2013-1-MG-INTRA_ACP, for a mobility grant to Ndzana Emma Julienne Augustine.

\section{Conflicts of Interest}

The authors declare no conflicts of interest regarding the publication of this paper.

\section{References}

[1] Boch, P. and Niepce, J.C. (2006) Ceramic Materials. ISTE Limited, France. https://doi.org/10.1002/9780470612415

[2] Njoya, D., Hajjaji, M., Baçaoui, A. and Njopwouo, D. (2010) Microstructural Characterization and Influence of Manufacturing Parameters on Technological Properties of Vitreous Ceramics Materials. Materials Characterization, 61, 289-295. https://doi.org/10.1016/j.matchar.2009.12.009

[3] Lemougna, P.N., Melo, U.C., Kamseu, E. and Tchamba, A.B. (2011) Laterit Based Stabilized Product for Sustainable Building Application in Tropical Countries. Review and Prospect for the Case of Cameroon. Sustainability, 3, 293-305. https://doi.org/10.3390/su3010293

[4] Permana, K.W.S., Paramarta, I.B.A. and Sumadiyasa, A.S.M. (2019) Stoneware Ceramic Synthesis with Iron Sand as a Filler Material. Journal of Materials Science and Chemical Engineering, 7, 42-51. https://doi.org/10.4236/msce.2019.78006

[5] Touolak, B.T. and Nya, F.T. (2014) More Value of Maroua Clay in the Formulation of Ceramic Products (Terracotta, Earthenware, Stoneware, Porcelain). Advances in Materials Physics and Chemistry, 4, 284-299. https://doi.org/10.4236/ampc.2014.412031 
[6] Staneva, N. and Kasabov, I. (1996) Influence of Electrolyte on the Casting Properties of Porcelain Slips. Interceram, 45, 12-15.

[7] Ergul, S., Akyildiz, M. and Karamanov, A. (2007) Ceramic Material from Basaltic Tuffs. Industrial Ceramics, 27, 1-7.

[8] Esposito, L., Salem, A., Tucci, A., Gualtieri, A. and Jazayeri, S.H. (2005) The Use of Nepheline Syenite in a Body Mix for Porcelain Stoneware Tiles. Ceramics International, 31, 233-240. https://doi.org/10.1016/j.ceramint.2004.05.006

[9] Das, S.K., Dana, K., Singh, N. and Sarkar, R. (2005) Shrinkage and Strength Behaviour of Quartzitic and Kaolinitic Clays in Wall Tile Composition. Applied Clay Science, 29, 137-143. https://doi.org/10.1016/j.clay.2004.10.002

[10] Vu, D.H., Wang, K.S., Chen, J.H. and Bac, B.X. (2012) Glass-Ceramic from Mixtures of Bottom Ash and Fly Ash. Waste Management, 32, 2306-2314. https://doi.org/10.1016/j.wasman.2012.05.040

[11] Kamseu, E., Bakop, T., Djangang, C., Melo, U.C., Hanuskova, M. and Leonelli, C. (2013) Porcelain Stoneware with Pegmatite and Nepheline Syenite Solid Solutions: Pore Size Distribution and Descriptive Microstructure. Journal of the European Ceramic Society, 33, 2775-2784. https://doi.org/10.1016/j.jeurceramsoc.2013.03.028

[12] Njindam, O.R., Njoya, D., Mache, J.R., Mouafon, M., Messan, A. and Njopwouo, D. (2018) Effect of Glass Powder on the Technological Properties and Microstructure of Clay Mixture for Porcelain Stoneware Tiles Manufacture. Construction and Building Materials, 170, 512-519. https://doi.org/10.1016/j.conbuildmat.2018.03.069

[13] Slavova, G. (2017) Global and Domestic Bulgarian Production of Cocoa and Chocolate Articles for the Period 2013-2016. Trakia Journal of Sciences, 15, 10-17. https://doi.org/10.15547/tjs.2017.s.01.003

[14] Fallo, J. (1999) Séminaire d'information sur les sous-produits du cacao. Fiche d'information, Ministère de la Recherche Scientifique et de l'Innovation. IRAD, Yaoundé.

[15] GretbagMacbeth (2000) Munsell Soil Color Charts. GretbagMacbeth, New Windsor.

[16] ASTM C 326-03. Standard Test Method for Drying and Firing Shrinkage of Ceramic Whiteware Clays. PA 19428-2959, United States. 1-2.

[17] ISO 10545-3 Carreaux et dalles céramiques. Partie 3: Détermination de l'absorption d'eau, de la porosité ouverte, de la densité relative apparente et de la masse volumique globale. 1-3.

[18] ISO 10545-4 Carreaux et dalles céramiques. Partie 4: Détermination de la résistance à la flexion et de la force de rupture 1-4.

[19] Pialy, P., Nkoumbou, C., Villiéras, F., Razafitianamaharavo, A., Barrès, O., Pelletier, M., Llivier, G., Bihannic, I., Njopwouo, D., Yvon, J. and Bonnet, J.P. (2008) Characterization for Industrial Applications of Clays from Lembo Deposit, Mount Bana (Cameroon). Clay Minerals, 43, 415-435.

https://doi.org/10.1180/claymin.2008.043.3.07

[20] Nkoumbuo, C., Njoya, A., Njoya, D., Grobois, C., Njopwwouo, D., Coutin-Nomade, A., Yvon, J. and Martin, F. (2009) Kaolin from Mayouom (Western Cameroon): Industrial Suitability Evaluation. Applied Clay Science, 43, 118-124. https://doi.org/10.1016/j.clay.2008.07.019

[21] Nzeukou, A.N., Flagel, N., Njoya, A., Kamgang, V.B., Medjo, R.E. and Melo, U.C. (2013) Mineralogy and Physic Chemical Properties of Alluvial Clays from Sanaga Valley (Center, Cameroon): Suitability for Ceramics Application. Applied Clay Science, 83-84, 238 243. https://doi.org/10.1016/j.clay.2013.08.038

[22] Konan, K.L., Sei, J., Soro, N.S., Oyetola, S., Gaillard, J.M., Bonnet, J.P. and Kra, G. 
(2006) Caractérisation de matériaux argileux du site d'Azaguie Blida (Anyama, Côte d'Ivoire) et détermination des propriétés mécaniques des produits céramiques. Journal de la Société Ouest-Africaine de Chimie, 21, 35-43.

[23] Rozenstrauha, I., Bajare, D., Cimdins, R., Berzina, L., Bossert, J. and Boccaccini, A.R. (2006) The Influence of Various Additions on Glass-Ceramic Matrix Composition Based on Industrial Waste. Ceramics International, 32, 115-119. https://doi.org/10.1016/j.ceramint.2005.01.006

[24] Lecomte, G., Pateyron, B. and Blanchart, P. (2004) Experimental Study and Simulation of a Vertical Section Mullite-Ternary Eutectic $\left(985^{\circ} \mathrm{C}\right)$ in the $\mathrm{SiO}_{2}-\mathrm{Al}_{2} \mathrm{O}_{3}-\mathrm{K}_{2} \mathrm{O}$ System. Materials Research Bulletin, 39, 1469-1478. https://doi.org/10.1016/j.materresbull.2004.04.024

[25] Lecomte, G.L., Bonnet, J.P. and Blanchart, P. (2007) A Study of the Influence of Muscovite on the Thermal Transformations of Kaolinite from Room Temperature up to $1100{ }^{\circ}$ C. Journal of Materials Science, $42,8745-8752$. https://doi.org/10.1007/s10853-006-0192-7

[26] Lecomte, G.L., Bonnet, J.P. and Soro, N. (2013) Influence of Iron into the Structural Reorganization Process during the Sintering of Kaolins. Journal of the European Ceramic Society, 4, 661-668. https://doi.org/10.1016/j.jeurceramsoc.2012.10.024

[27] Kamseu, E., Rizzuti, A., Leonelli, C. and Perera, D. (2010) Enhanced Thermal Stability in $\mathrm{K}_{2} \mathrm{O}$-Metakaolin-Based Geopolymer Concretes by $\mathrm{Al}_{2} \mathrm{O}_{3}$ and $\mathrm{SiO}_{2}$ Fillers Addition. Journal of Materials Science, 45, 1715-1724. https://doi.org/10.1007/s10853-009-4108-1

[28] Traore, K., Kabre, T.S. and Banchart, P. (2001) Sintering of Clay from Burkina Faso by Dilatometry, Influence of the Applied Load and the Pre-Sintering Heating Rate. Ceramics International, 27, 875-822. https://doi.org/10.1016/S0272-8842(01)00043-8

[29] Seynou, M., Millogo, Y., Ouedraogo, R., Traoré, K. and Tirlocq, J. (2011) Firing Transformations and Properties of Tiles from a Clay from Burkina Faso. Applied Clay Science, 51, 499-502. https://doi.org/10.1016/j.clay.2011.01.002

[30] Aliprandi, G. (1979) Matériaux réfractaires et céramiques techniques. Septima, Paris.

[31] Elimbi, A. and Njopwwouo, D. (2002) Firing Characteristics of Ceramics from the Bomkoul Kaolinite Clay Deposit (Cameroon). Tile \& Brick International, 18, 364-369.

[32] Brindley, G.W. and Brown, G. (1980) Crystal Structures of Clay Minerals and Their X-Ray Identification. Mineralogical Society Monograph No. 5, London, Chapter 6. https://doi.org/10.1180/mono-5

[33] Trindade, M.J., Dias, M.I., Coroado, J. and Rocha, F. (2008) Mineralogical Transformations of Calcareous Rich Clays with Firing: A Comparative Study between Calcite and Dolomite Rich Clays from Algarve, Portugal. Applied Clay Science, 42, 345-355. https://doi.org/10.1016/j.clay.2008.02.008

[34] Vassileva, C. and Vassilev, S. (2004) Some Environmental Aspects Related to Sulphuremissions during Combustion of Bulgarian Coals. Comptes rendus de P Academie Bulgare des Sciences, 57, 29-32.

[35] Deniel, S. (2010) Elaboration et caractérisation de céramiques texturées de mullite à partir de phyllosilicates. PhD Dissertation, Université de Limoges, Limoges.

[36] Sokolar, R. (2010) Effect of Calcite on the Brick Body Closing. Interceram, 59, 57-62.

[37] Sokolar, R., Vodova, L., Grygarova, S., Stubna, I. and Sin, P. (2012) Mechanical Properties of Ceramic Bodies Based on Calcite Waste. Ceramics International, 38, 6607-6612. https://doi.org/10.1016/j.ceramint.2012.05.046 
[38] Elimbi, A., Dika, J.M. and Djangang, C.N. (2014) Effects of Alkaline Additives on the Thermal Behavior and Properties of Cameroonian Poorly Fluxing Clay Ceramics. Journal of Minerals and Materials Characterization and Engineering, 2, 484-501. https://doi.org/10.4236/jmmce.2014.25049

[39] Dondi, M., Raimondo, M. and Zanelli, C. (2014) Clays and Bodies for Ceramic Tiles: Reappraisal and Technological Classification. Applied Clay Science, 96, 91-109. https://doi.org/10.1016/j.clay.2014.01.013 